\title{
Effects of salvage logging on soil properties and vegetation recovery in a fire-affected Mediterranean forest: A two year monitoring research
}

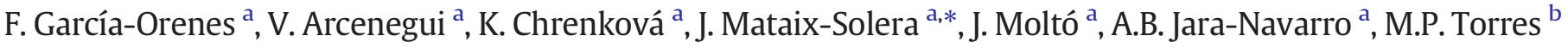 \\ a GEA, Department of Agrochemistry and Environment, University Miguel Hernández, Avda. de la Universidad s/n, Elche, 03202, Alicante, Spain \\ b Department of Applied Biology, University Miguel Hernández, Avda. de la Universidad s/n, Elche, 03202, Alicante, Spain
}

\section{H I G H L I G H T S}

- Mediterranean soils developed over marls are very vulnerable to degradation after wildfire.

- Post-fire salvage logging affects soil quality over short- and medium-terms.

- Plant recovery is also affected by salvage logging treatments after forest fire.

- Reduced plant cover and lower soil quality could increase soil erosion rates.
G R A P H I C A L A B S T R A C T

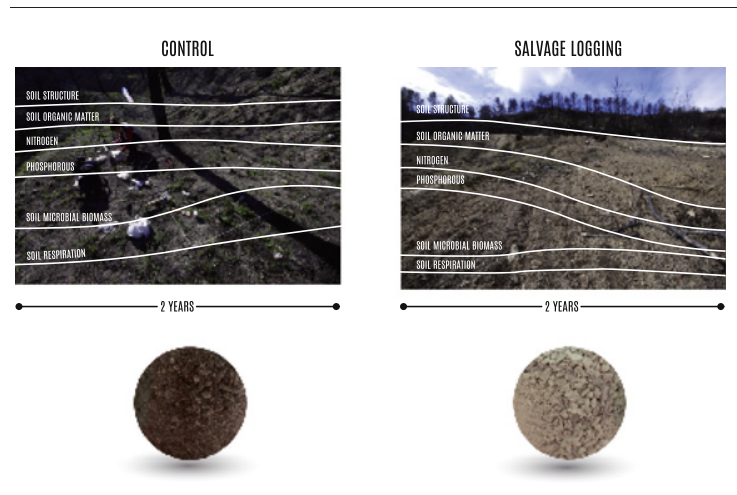

\section{A B S T R A C T}

Post-fire management can have an additional impact on the ecosystem; in some cases, even more severe than the fire. Salvage logging (SL) is a common practice in most fire-affected areas. The management of burnt wood can determine microclimatic conditions and seriously affect soil properties. In some cases, the way of doing it, using heavy machinery, and the vulnerability of soils to erosion and degradation can make this management potentially aggressive to soil. Research was done in "Sierra de Mariola Natural Park" (E Spain). A forest fire (>500 ha) occurred in July 2012. In February 2013, SL treatment was applied in a part of the affected forest. Plots for monitoring this effect were installed in this area and in a similar nearby area where no treatment was done, used as control (C). Soil samplings were done immediately after treatment and every 6 months during two years. Some soil properties were analysed, including organic matter $(\mathrm{OM})$ content, nitrogen $(\mathrm{N})$ available phosphorous $(P)$ basal soil respiration (BSR), microbial biomass carbon $\left(C_{\text {mic }}\right)$, bulk density $(B D)$, water repellency (WR), aggregate stability (AS) and field capacity (FC). SL treatment caused an increase in BD, a decrease of AS, $\mathrm{FC}, \mathrm{OM}$ and $\mathrm{N}$. In the control area, in general the soil properties remained constant across the 2 years of monitoring, and the microbial parameters (BSR and $C_{\text {mic }}$ ), initially affected by the fire, recovered faster in C than in the SL area. Plant recovery also showed some differences between treatments. No significant differences were observed in the number of plant species recorded (richness) comparing C versus SL plots, but the number of individuals of each species (evenness) was significantly higher in C plots. In conclusion, we can affirm that for the conditions of this study case, SL had a negative effect on the soil-plant system.

(c) 2017 Elsevier B.V. All rights reserved.

\footnotetext{
* Corresponding author.

E-mail address: jorge.mataix@umh.es (J. Mataix-Solera).
} 


\section{Introduction}

Forest fires are part of the natural dynamic of the terrestrial ecosystem (Le Houerou, 1977; Naveh, 1975), and are also reflected in the fossil record and the great number of species adaptation due to this natural disturbance. The Mediterranean ecosystems have been and currently are very influenced by this phenomenon, as fire is a recurrent fact in the Mediterranean area, and one of the main causes of changes in these ecosystems. Fire induces changes in soil properties (e.g.: Andreu et al., 1994; Cerdà, 1996; Certini, 2005; Llovet et al., 2008), and can have an impact on soil productivity of burnt areas (Robichaud, 2009) especially when they are affected by huge and high intensity fires such as those that are frequent in some summer seasons under extreme weather conditions.

Post-fire management can have a negative impact on the soils being in some cases even more severe than the fire itself. Salvage logging (SL) is a common management technique in fire-affected areas, comprising the extraction of the burnt wood and in many cases using heavy machinery and dragging the trunks over soil, leading to a consequent increase in its vulnerability to erosion and soil degradation (Mataix-Solera et al., 2015, 2016).

González-Ochoa et al. (2004), Martínez-Sánchez et al. (1999), Pausas et al. (2004), Vega et al. (2008), and Griffin et al. (2013), among others, studied the vegetation dynamic in areas affected by fires and where SL treatments were applied. All of them concluded that to a greater or lesser degree there was a negative influence on plant recovery. Wagenbrenner et al. (2016), Morgan et al. (2014) and Sexton (1998) observed, reduced vegetation cover in areas where SL treatment was used compared to unlogged areas. Vegetation recovery after post-fire SL might have been hampered by the soil compaction (Page-Dumroese et al., 2006) or lower water availability (MarañónJiménez et al., 2013) caused by the equipment traffic. Numerous studies have demonstrated that soil compaction in forested environments can also persist for several decades, which can impede plant development for prolonged time periods (Wert and Thomas, 1981; Froehlich et al., 1985; Vora, 1988; Reisinger et al., 1992; Brevik, 2013).

Previous studies have shown that post-fire logging can increase soil disturbance and erosion (Klock, 1975; Mclver and Starr, 2001; Mclver and McNeil, 2006; Slestak et al., 2015; Wagenbrenner et al., 2015; Peterson and Dodson, 2016), alter the cover and composition of recovering native vegetation (Stuart and Grifantini, 1993; Purdon et al., 2004; Keyser et al., 2009; Ritchie et al., 2013), damage natural tree regeneration (Keyser et al., 2009) and increase surface woody fuels within 2-4 years after fire and logging (Donato et al., 2006).

There are several factors contributing to the increased runoff rates and erosion after SL treatment. Wagenbrenner et al. (2016) attributed the increase in runoff after logging equipment traffic to lower infiltration rates resulting from reduced micro and macro soil porosity (Ares et al., 2005; Horn et al., 2004; Startsev and McNabb, 2000), associated it with an increase in soil compaction. Wilson (1999), in his rainfall simulation experiments found that post-fire SL did increase surface runoff and erosion in part caused by the disruption of the biotic crust by heavy equipment. However, in NE Spain Marques and Mora (1998), observed that the sediment yields in burned areas as a consequence of the SL treatment were moderately low, and recently in NW Spain, Fernández and Vega (2016) didn't find any detrimental effect of SL treatment compared to natural regeneration. These contradictory results could be due to factors such as type of soil, when and how the SL treatment is carried out, and meteorological conditions which can be decisive.

Little is known about what effect this kind of treatment has in soil properties and how this can affect the ecosystem response to the fire and post-fire managements. Marañón-Jiménez et al. (2011) observed a decrease in soil respiration after salvage logging treatment, and Serrano-Ortiz et al. (2011) a negative impact for potential carbon sequestration. Post-fire SL treatment reduces the vegetation cover
(Serrano-Ortiz et al., 2011; Wagenbrenner et al., 2016), and affects soil micro-climate (Lindenmayer and Noss, 2006), decomposition, and ecosystem carbon storage capacity. Moreover, post-fire SL can reduce organic matter input to the soil by removing the standing dead trunks that would eventually fall and contribute to soil organic carbon storage (Smith et al., 2000; DeLuca and Aplet, 2008; Moroni et al., 2010; Seedre et al., 2011). All these factors can also provoke a fast response in microbial properties, producing important changes in the content of microorganisms and their activity (Burton et al., 2000; Nadelhoffer, 2000; Tang et al., 2003).

In this research we studied the immediate, short and medium-term effect ( 2 years of monitoring) of a SL treatment applied in a recently burned area ( 6 months after fire) with a soil vulnerable to degradation in physical, chemical and microbial soil properties, and also in the restoration of vegetation recovery, by comparison with no treatment (control) to study whether this management can have an impact on soil quality and the magnitude of these changes.

\section{Materials and methods}

\subsection{Study site}

The study area is located in "Sierra de Mariola Natural Park" in Alcoi, Alicante (E Spain). Coordinates of the study area are $38^{\circ} 43^{\prime} 59^{\prime \prime} \mathrm{N}, 0^{\circ} 29^{\prime}$ $16^{\prime \prime} \mathrm{W}$. This area has a Mediterranean climate with 3-4 months of summer drought, usually from late June till September. This climate is characterised by a dry-hot summer and a wet-warm spring, autumn and winter. The annual average precipitation is $490 \mathrm{~mm}$, which falls mainly in October-November (maximum rainfall in October, $71 \mathrm{~mm}$ ). Mean monthly temperature is $14.8{ }^{\circ} \mathrm{C}$ (summer: $22.7{ }^{\circ} \mathrm{C}$, winter: $7.9^{\circ} \mathrm{C}$ ). The forest is composed mainly of Pinus halepensis trees of around 40 years old with an understory of typical Mediterranean shrubs species such as Quercus coccifera, Rosmarinus officinalis, Thymus vulgaris, Brachypodium retusum, etc. The soil is classified as a Typic Xerorthent (Soil Survey Staff, 2014) developed over marls with a low depth, very vulnerable to erosion and degradation processes, with $4.6 \%$ of organic matter content in first $5 \mathrm{~cm}$ soil depth, a loam soil texture with 45, 39 and $17 \%$ of sand, silt and clay respectively, and $44 \%$ of carbonates.

A forest fire of moderate severity occurred in July 2012 affecting a total of 546 has. Six months after the forest fire, in February 2013, salvage logging (SL) treatments consisting of a complete extraction of the burned wood using heavy machinery was applied in a part of the affected forest. In the pictures of Fig. 1 an example of specific areas where logs were gathered and dragged onto the road during and just after the extraction of wood can be observed.

\subsection{Experimental design, vegetation monitoring, soil samplings and analysis}

Three plots of $4 \mathrm{~m}^{2}$ for monitoring this effect were installed in this area and another three in a similar nearby area where no treatment was done, which were then used as control (C) for comparison. All plots in both treatments were chosen with the same aspect and slope for comparable results (Fig. 2). The six plots were monitored for plant recovery. In these plots, three seasonal periods were observed, autumn 2013, spring and autumn 2014. The following parameters were determined: Richness (number of plant species for each plot), Evenness (number of individuals of each species) and Diversity. The Shannon-Weaver $\left(\mathrm{H}^{\prime}\right)$ index was calculated as a measure of diversity, as it combines two components of diversity, i.e., species richness and evenness. It is calculated from the equation $\mathrm{H}^{\prime}=-\Sigma p i(\ln p i)$, where $p i$ is the proportion of individuals found in the $i$ th species.

Soils samplings were done immediately after post-fire treatments and every 6 months, until a total of five soil samplings were made in areas near the plots for plant recovery. Three soil samples $(0-5 \mathrm{~cm}$ depth) per plot were collected from the A soil mineral horizon $(\mathrm{n}=9$ 

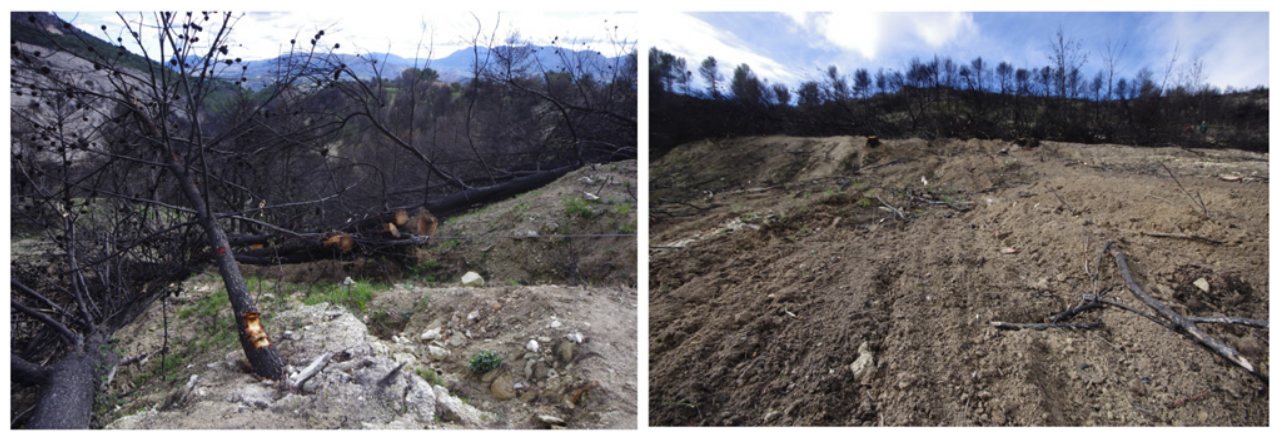

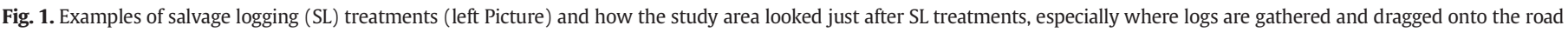
(right picture). Photos: J. Mataix-Solera, 2013.

samples per treatment and per sampling; total $n=135$ samples). The election of the depth of soil sampling was decided after estimations of the averaged mineral soil depth affected by the SL treatments. In some specific areas where logs were gathered and dragged, the affected soil depth was higher, but not representative. These specific areas were avoided to install the plots and all of them were installed in the most representative places after the treatment.

For every soil sample an aliquot was kept under $4{ }^{\circ} \mathrm{C}$ to measure the microbiological parameters, and the rest of the soil sample was dried at room temperature and sieved apart between 4 and $0.25 \mathrm{~mm}$ for Aggregate Stability (AS) tests and the remaining $2 \mathrm{~mm}$ for the rest of the physico-chemical analysis. In all the samples the organic matter content (OM), aggregate stability (AS), soil water repellency (WR), bulk density (BD), Kjeldahl N, available phosphorus (P), field capacity (FC), basal soil respiration (BSR) and microbial biomass carbon content $\left(C_{\text {mic }}\right)$ were determined. Soil OM was determined by the potassium dichromate oxidation method (Nelson and Sommers, 1982). AS was measured with the method of Roldán et al. (1994), based on the method of Benito and Díaz-Fierros (1989). This method examines the proportion of aggregates that remain stable after a soil sample (sieved between 4 and $0.25 \mathrm{~mm}$ ) is subjected to an artificial rainfall of known energy $\left(270 \mathrm{~J} \mathrm{~m}^{-2}\right.$ ). Persistence of soil water repellency (WR) was assessed by the Water Drop Penetration Time (WDPT) test (Wessel, 1988). Approximately $10 \mathrm{~g}$ of air-dried sample $(<2 \mathrm{~mm})$ was placed into separate plastic dishes (diameter $50 \mathrm{~mm}$ ), and exposed to a controlled laboratory atmosphere $\left(20^{\circ} \mathrm{C}, 50 \%\right.$ relative humidity) for $24 \mathrm{~h}$ to eliminate potential effects of any variations in preceding atmospheric humidity on WR (Doerr et al., 2002). The average time for triplicate drops is taken as the WDPT value of a sample, and then classified according to Bisdom et al. (1993) and Doerr et al. (1998), as follows: wettable (WDPT < $5 \mathrm{~s}$ ), slightly water repellent (WDPT: 5-60 s), strongly water repellent (WDPT: 60-600 s), severely water repellent (WDPT: 600$3600 \mathrm{~s}$ ), and extremely water repellent (WDPT > $3600 \mathrm{~s}$ ).
Total nitrogen was determined by the Kjeldahl method (Bremner and Mulvaney, 1982). Available phosphorus was determined by the Burriel-Hernando method (Díez, 1982). Field capacity was assayed by the method of Forster (1995). $\mathrm{C}_{\text {mic }}$ was determined by the fumigationextraction method (Vance et al., 1987). The basal respiration of soil was measured in a multiple sensor respirometer (Micro-Oxymax, Columbus, $\mathrm{OH}, \mathrm{USA}$ ).

In the case of bulk density we performed soil samplings more frequently during the first year (one per month) trying to get more information as to whether soil compaction as a consequence of treatment could happen in the short-term. Bulk density was measured using undisturbed soil cores of $100 \mathrm{~cm}^{3}$.

\subsection{Statistical analyses}

The fitting of the data to a normal distribution for all soil properties was checked with the Kolmogorov-Smirnov test at $\mathrm{p}<0.05$. To compare post-fire treatments effect (SL versus $C$ ), $t$-test for independent samples, for every one of the soil samplings was used; also a one-way ANOVA was carried out to know the differences between samplings (temporal changes) for each one of the two treatments. The separation of means was carried out according to the average post-hoc Tukey test $\mathrm{p}<0.05$, assuming equal variance. Redundancy analysis (RDA) was used to examine the relationship between the soil treatment and soil characteristics. Soil physical, chemical and microbial properties were tested for significant contributions to the variation data using the Monte Carlopermutation test $(\mathrm{p}<0.05)$. Only the soil properties that were significantly correlated with factors in the RDA were included. Vectors represent soil properties. Vectors of greater magnitude that form smaller angles with an axis are more strongly correlated with that axis. All statistical analysis was performed with the SPSS program (Statistical Program for the Social Sciences 18.0). RDA was performed using CANOCO for Windows v. 4.5.3
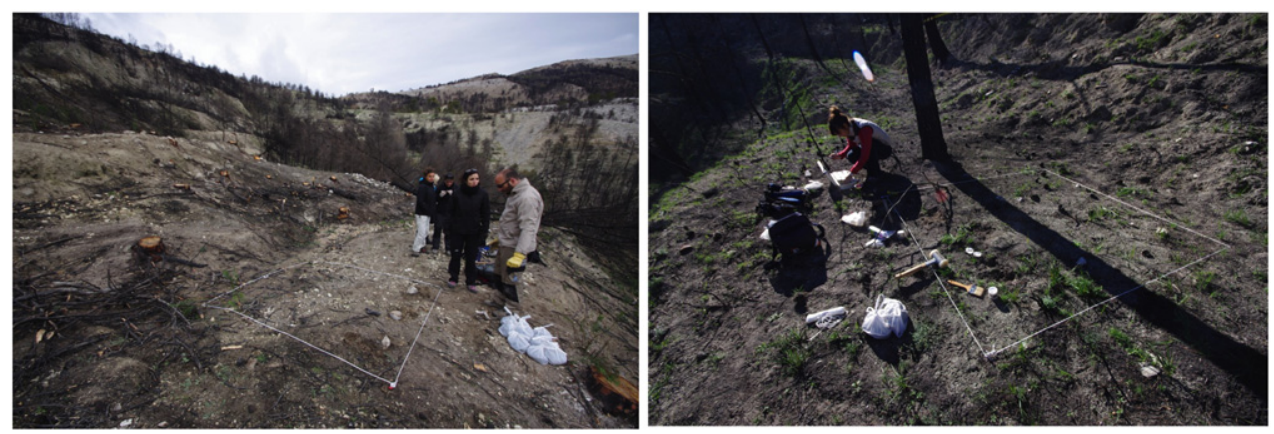

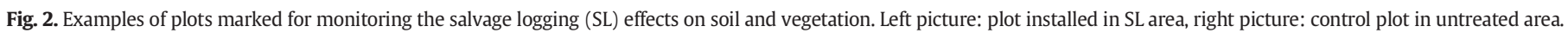
Photos: J. Mataix-Solera, 2013. 


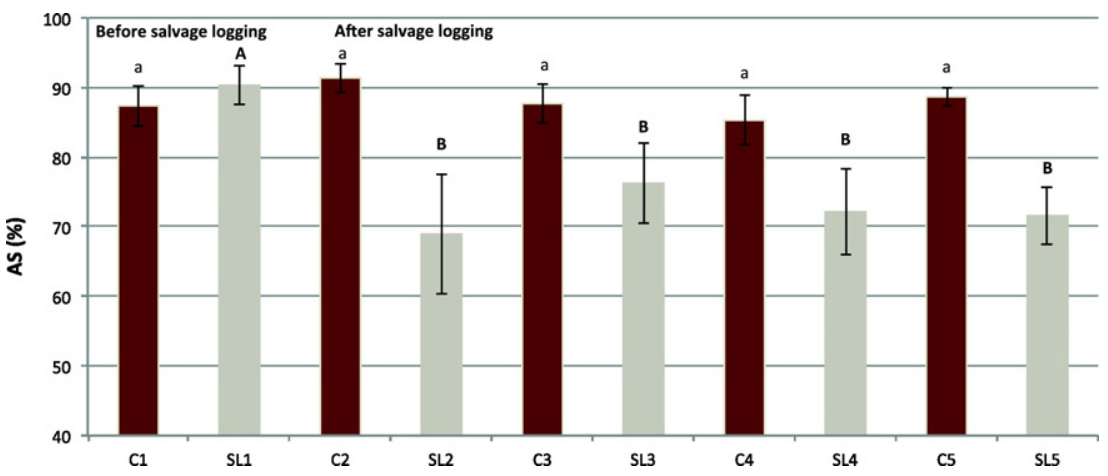

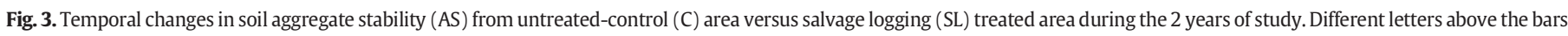
indicate significant differences between soil sampling periods (1-5), in capital and bold for SL treatment.

\section{Results}

\subsection{Soil physical properties ( $B D, A S, W R$ and $F C)$}

One of the physical effects of SL was compaction of the soil surface layer, indicated by an increasing trend of BD and a decrease of AS. Bulk density of this type of soil is relatively low since the parent material (marls) has a low real density. In the control area the BD varied between $0.72 \pm 0.08$ to $0.78 \pm 0.07 \mathrm{~g} \mathrm{~cm}^{-3}$ and without statistical differences throughout the whole study period. However, in the area with SL treatment a progressive tendency to increase was measured with an initial value of $0.62 \pm 0.06$ for the first soil sampling, to $0.83 \pm 0.09 \mathrm{~g} \mathrm{~cm}^{-3}$ at the end of the study period, with statistical differences $(\mathrm{p}<0.05)$ two years after the treatment, indicating a compaction of soil.

In Fig. 3, we can observe the evolution of AS for both treatments. After the fire, the percentage of AS was high, around 90\%. SL treatment clearly provoked a decrease in AS (around 20\%) that was observed 6 months after treatment and this difference was maintained until the end of the study. The control soils were able to maintain the same level of AS during the whole study period. This property is closely related with $\mathrm{BD}$, and due to the SL treatment, the destruction of part of the aggregates contributed to clog soil pores and therefore increased the BD.

The field capacity shows high variability in values but in general we observed lower mean values in the SL area than in the C plots $(\mathrm{p}<0.05)$

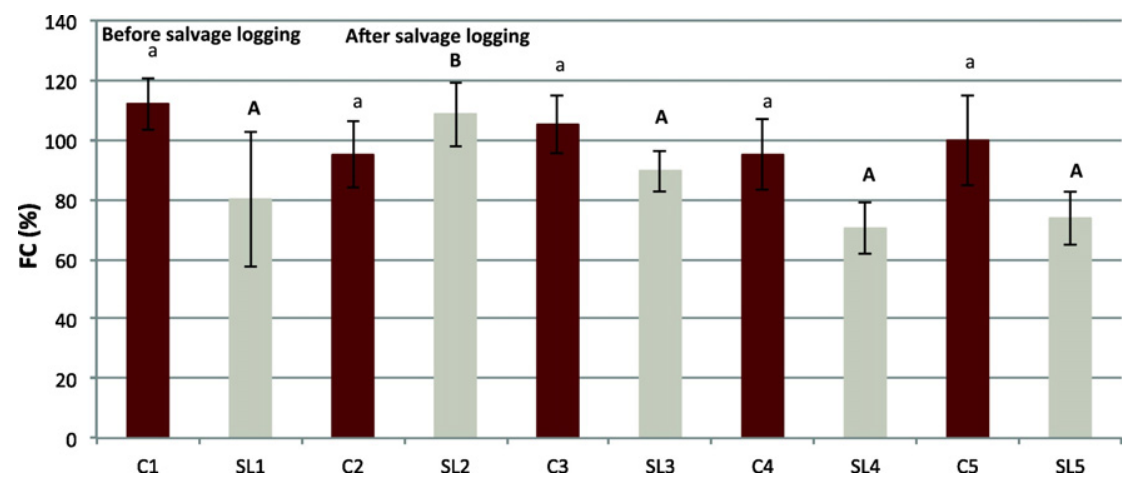

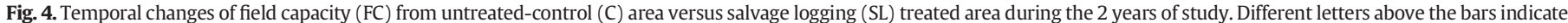
significant differences between soil sampling periods (1-5), in capital and bold for SL treatment.

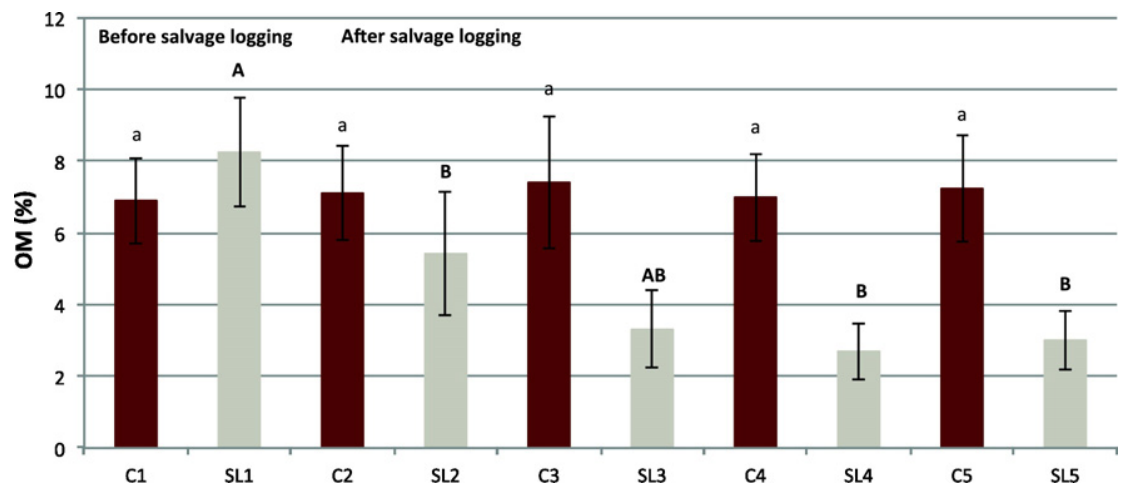

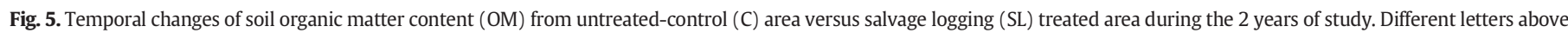
the bars indicate significant differences between soil sampling periods (1-5), in capital and bold for SL treatment. 
Table 1

Differences between treatments for every sampling along the experiment. Significant at: ${ }^{*} \mathrm{p}<0.05,{ }^{* *} \mathrm{p}<0.01 ;{ }^{* * *} \mathrm{p}<0.001$; ns: not significant ( $\mathrm{p}>0.05$ ).

\begin{tabular}{llllll}
\hline Parameter & Sampling 1 & Sampling 2 & Sampling 3 & Sampling 4 & Sampling 5 \\
\hline AS & ns & $* * *$ & $* * *$ & $* * *$ & $* * *$ \\
FC & $* *$ & ns & $* *$ & $* * *$ & $* *$ \\
P & ns & ns & $* *$ & ns & $* * *$ \\
OM & ns & ns & $* * *$ & $* * *$ & $* * *$ \\
N & ns & ns & $* *$ & $* * *$ & $* * *$ \\
BSR & ns & $* *$ & ns & $* *$ & $* * *$ \\
C $_{\text {mic }}$ & ns & $*$ & $* * *$ & $* * *$ & $* * *$ \\
\hline
\end{tabular}

AS: aggregate stability; FC: field capacity; P: available phosphorous; OM: organic matter content; $\mathrm{N}$ : nitrogen; BSR: basal soil respiration, $\mathrm{C}_{\text {mic }}$ : microbial biomass carbon.

for most of soil samplings (Fig. 4). Soil WR was not detected in any soil sample at any period of soil sampling (WDPT $<5 \mathrm{~s}$ ).

\subsection{Soil organic matter content, nitrogen and available phosphorous}

As we can see in Fig. 5, the OM content in the SL area shows a significant and important progressive decrease during the whole study period, reaching less than half of the initial content in the last sampling. We also found statistically significant differences in OM content between treatments for the three last samplings ( $\mathrm{p}<0.001$; Table 1$)$. The control area did not show variations for this parameter, keeping the initial soil OM content constant during the whole study period (Fig. 5).

The behaviour of $\mathrm{N}$ is similar to the OM content. The area that has suffered the wood extraction showed a significant decrease of the $\mathrm{N}$ content (50\%) during the study period. Soil of control plots has kept its $\mathrm{N}$ content during the first samplings increasing it significantly from the third sampling. We found significant differences between the two treatments in last three samplings after SL (Fig. 6 and Table 1).
Fig. 7 shows the evolution of available P during the study period, there were almost no differences for this parameter between treatments especially at the start of the study, although some lower mean values for SL treatment were obtained from the third soil sampling but with high variability of data. The soil of $C$ area kept the same levels of available P during all the study period.

\subsection{Microbial biomass carbon and soil basal respiration}

One of the parameters most directly affected by the fire in the soil was the $C_{\text {mic }}$, as can be observed in Fig. 8, very low values were registered in all the experimental areas during the first two soil samplings, these values being below $300 \mathrm{mg} \mathrm{C} \mathrm{kg}{ }^{-1}$ soil. In general the average content of $C_{\text {mic }}$ in forest soils of our region is in the range of 800$1200 \mathrm{mg} \mathrm{C} \mathrm{kg}{ }^{-1}$ soil (Zornoza et al., 2007; Garcia-Orenes et al., 2012). It has been observed that the control area showed a good recovery of microbial populations after the third sampling reaching mean $C_{\text {mic }}$ values of $1200 \mathrm{mg} \mathrm{C} \mathrm{kg}^{-1}$ at the end of the study period, while the average value in the soils of the SL treated area was below $600 \mathrm{mg} \mathrm{C} \mathrm{kg}^{-1}$ at the end of the study.

A similar behaviour has been observed in BSR with a lower activity immediately after fire in all the samples studied (Fig. 9). The soil of the control area was recovering microbial activity in the following samplings while the area with SL treatment showed lower values relative to the control, this being statistically significant at the two last soil sampling periods (Table 1 ).

The RDA performed on all data (Fig. 10) showed that the first two axes could explain $72 \%$ of the total variation. Axis 1 separated SL samples of C samples and explained 58\%. All soil physical, chemical and microbial properties were significant $(\mathrm{p}<0.05)$. The variable AS accounted for a large amount of the variation in the distribution of samples along axis 1 . The RDA has showed an important and significant difference of behaviour in the majority of the properties studied between SL and C

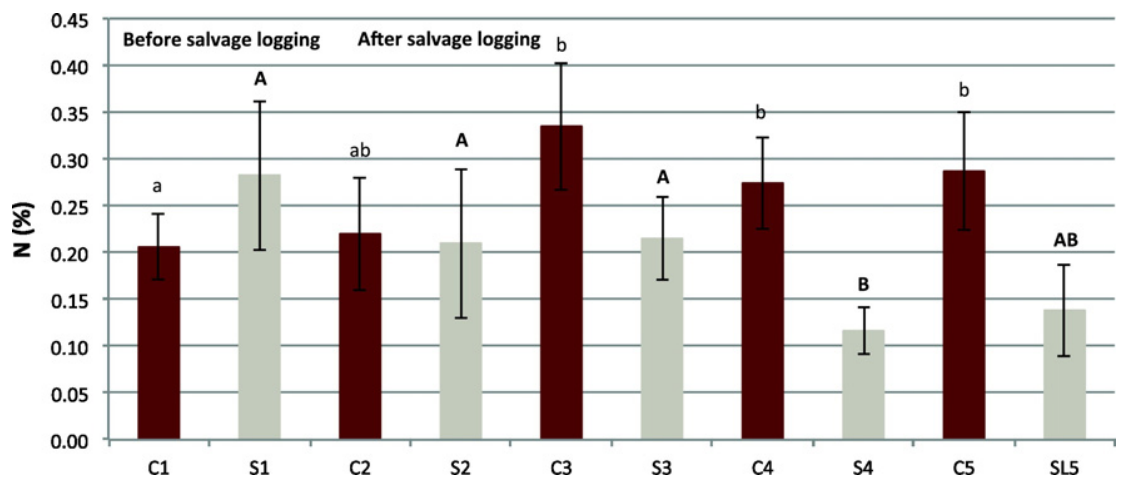

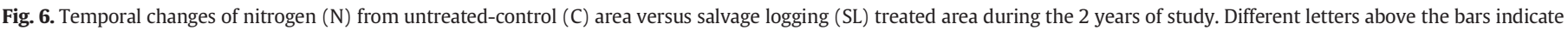
significant differences between soil sampling periods (1-5), in capital and bold for SL treatment.

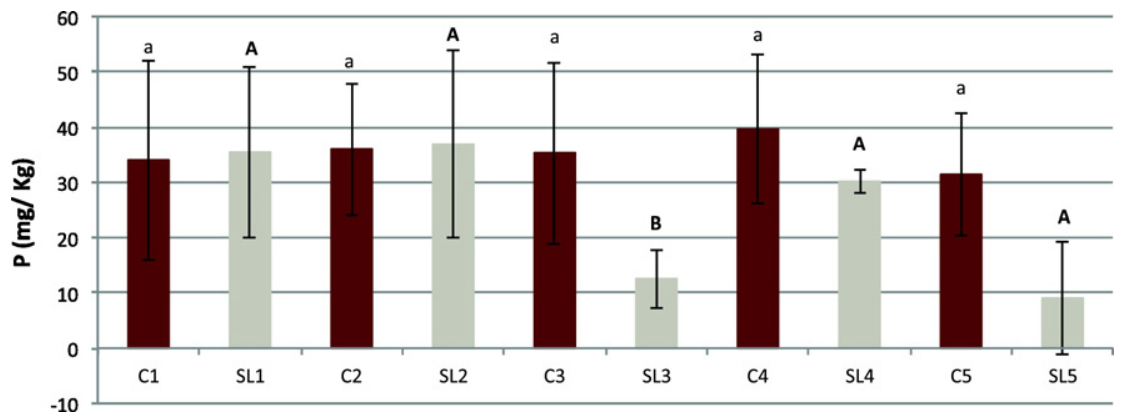

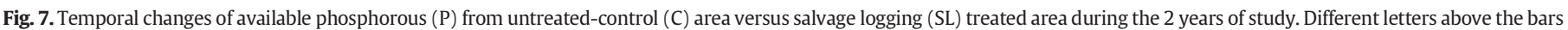
indicate significant differences between soil sampling periods (1-5), in capital and bold for SL treatment. 


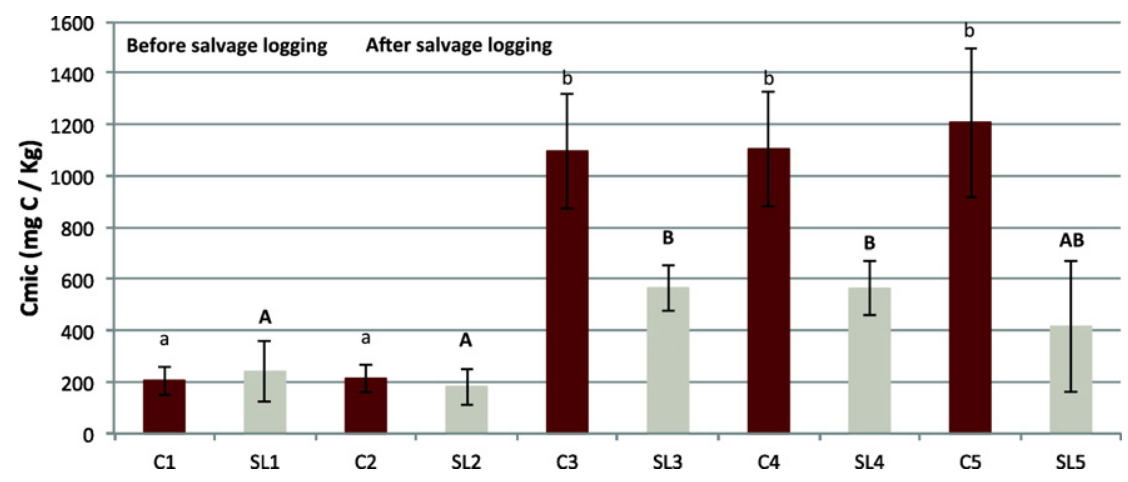

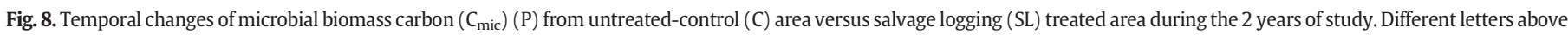
the bars indicate significant differences between soil sampling periods (1-5), in capital and bold for SL treatment.

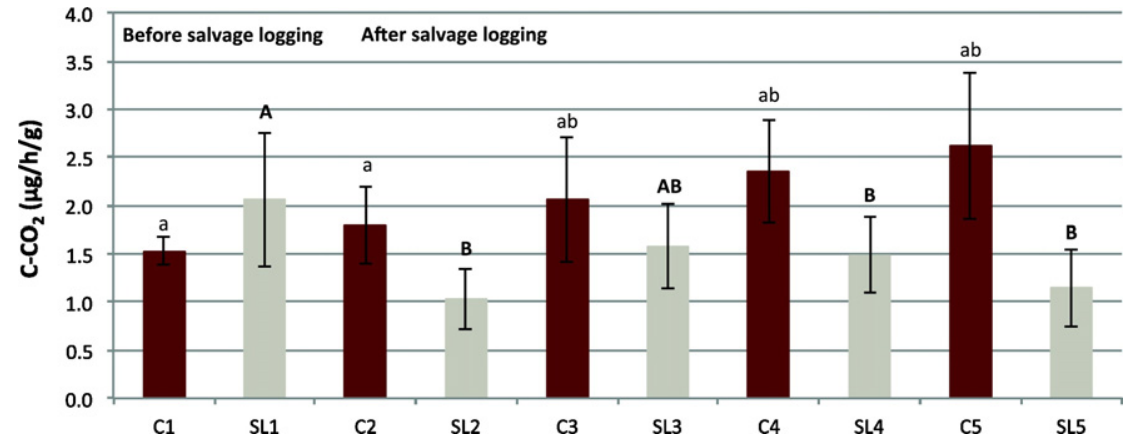

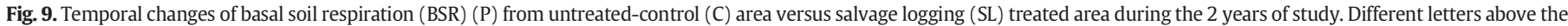
bars indicate significant differences between soil sampling periods (1-5), in capital and bold for SL treatment.

samples, these differences have been specially marked in microbiological properties $\mathrm{C}_{\text {mic }}$ and BSR and $\mathrm{N}$ that were strongly related with samples from the control area.

\subsection{Plant recovery}

No significant differences were observed in the number of plant species recorded (richness) comparing plots with SL treatment versus

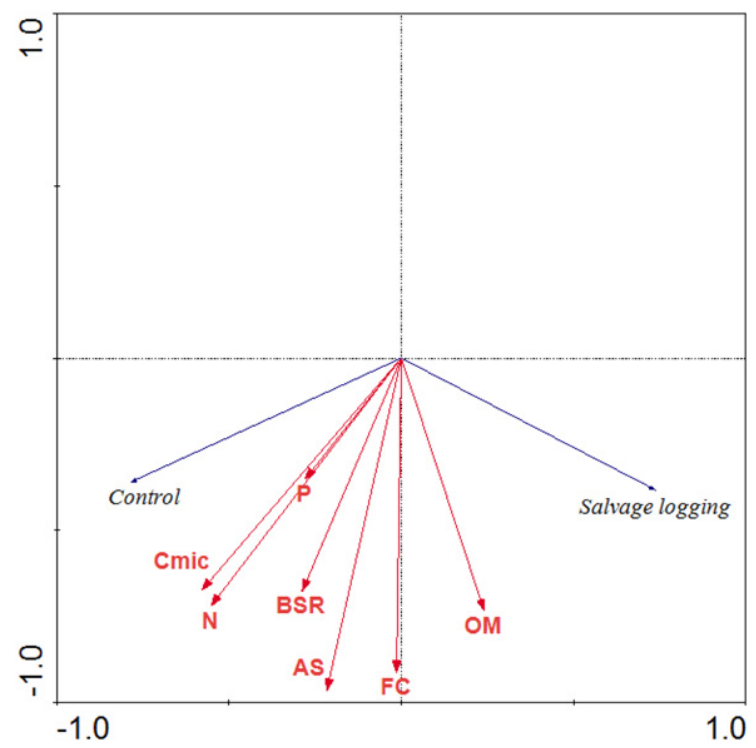

Fig. 10. RDA analysis performed with all data. AS: aggregate stability; FC: field capacity; P: available phosphorous; OM: organic matter content; N: nitrogen; BSR: basal soil respiration, $\mathrm{C}_{\text {mic }}$ : microbial biomass carbon. control (untreated) plots (Table 2) in the three samples conducted, but the number of individuals of each species (evenness) was always significantly higher in $\mathrm{C}$ plots.

These differences were highly significant in the case of some species such as Pinus halepensis, that presented an average of 20 individuals in the SL plots and $>300$ individuals in the C plots (in autumn 2014).

Regarding diversity results (Shannon-Weaver index) differences between treatments were not statistically significant (Table 2). In annex (supplement) are details of all plant species that appeared in both $\mathrm{C}$ and SL areas.

\section{Discussion}

Post-fire management has engendered a great debate about the correct method to recover soil properties affected after fire (Beschta et al., 2004; Donato et al., 2006; Lindenmayer et al., 2004; McIver and Starr, 2001). In the last two decades SL has been a common practice after fire, but recent studies have reported that this treatment may impact ecosystem function and regeneration (Donato et al., 2006; Lindenmayer and Noss, 2006; Castro et al., 2010, 2011). In our study, post-fire SL management clearly produced a general degradation of soil as indicated by most of the soil parameters analysed. Physically, soil suffered compaction, indicated by an increase in bulk density and a loss of AS. The results of BD are similar to those observed by Wagenbrenner et al. (2015) in a study of the effect of SL on soil in the western USA; they found that the soil compaction due to logging using machinery extended to a depth of at least $10 \mathrm{~cm}$ and relatively few passes of the logging equipment resulted in substantial soil compaction. In our case we think it is more due to the loss of vegetation cover, the progressive loss of OM during the study period, and the destruction of a part of the aggregates producing an increase in BD. Soil OM content and AS are very closely and positively correlated in the forest soils of the region (Chrenková et al., 2014). The loss of OM, and the 
Table 2

Plant recovery parameters measured and differences between treatments for every monitored period. Significant at: ${ }^{*} \mathrm{p}<0.05$, ${ }^{* *} \mathrm{p}<0.01$; ${ }^{* * *} \mathrm{p}<0.001$; ns: not significant ( $\mathrm{p}>0.05$ ).

\begin{tabular}{|c|c|c|c|c|c|c|c|c|c|}
\hline & \multicolumn{3}{|c|}{ Autumn 2013} & \multicolumn{3}{|l|}{ Spring 2014} & \multicolumn{3}{|c|}{ Autumn 2014} \\
\hline & Richness & Evenness & $\mathrm{H}^{\prime}$ & Richness & Evenness & $\mathrm{H}^{\prime}$ & Richness & Evenness & $\mathrm{H}^{\prime}$ \\
\hline $\mathrm{C}$ & $9.5 \pm 1.2$ & $222.3 \pm 58.0$ & $0.55 \pm 0.06$ & $12.0 \pm 2.0$ & $221.5 \pm 58.8$ & $0.64 \pm 0.10$ & $10.2 \pm 0.9$ & $275.6 \pm 19.8$ & $0.58 \pm 0.04$ \\
\hline SL & $\begin{array}{l}8.7 \pm 1.6 \\
\mathrm{~ns}\end{array}$ & $\begin{array}{l}66.2 \pm 40.8 \\
*\end{array}$ & $\begin{array}{l}0.64 \pm 0.05 \\
\mathrm{~ns}\end{array}$ & $\begin{array}{l}9.6 \pm 2.5 \\
\text { ns }\end{array}$ & $\begin{array}{l}77.4 \pm 22.0 \\
*\end{array}$ & $\begin{array}{l}0.72 \pm 0.03 \\
\mathrm{~ns}\end{array}$ & $\begin{array}{l}8.2 \pm 1.8 \\
\text { ns }\end{array}$ & $\begin{array}{l}104.9 \pm 36.6 \\
* *\end{array}$ & $\begin{array}{l}0.51 \pm 0.05 \\
\text { ns }\end{array}$ \\
\hline
\end{tabular}

effect on soil structure can also be responsible for the lower FC measured in the SL area in most of the soil samplings (Table 1). This alteration of soil structure produces an increase in the erosion rates, also a consequence of the lower vegetation cover (Larsen et al., 2009; Wagenbrenner and Robichaud, 2014). In the case of WR, soils of both treatments showed wettable conditions during the whole study period. This result is not strange since fires do not always induce or increase $\mathrm{WR}$, because many factors are involved, such as temperatures reached during burning (Arcenegui et al., 2007), and also soil type and properties can control its presence and development by burning (MataixSolera et al., 2014).

The OM in the soils with post-fire SL treatment decreased from $7 \%$ to $<3 \%$ in first $5 \mathrm{~cm}$ soil depth; this loss of OM is higher than losses observed as a direct consequence of high intensity forest fires in the Mediterranean area (Mataix-Solera et al., 2002). However in the case of the control area the OM content remained stable without decreasing in the whole study period. Some authors suggest that the decrease in OM content after the fire can be due to erosion (Hatten et al., 2005). In our case, the results of the SL area suggest this area has suffered higher erosion rates than the $C$ area, and this fact could be the main cause of the progressive reduction of $\mathrm{OM}$ content together with conditions more prone to $\mathrm{OM}$ mineralization rates, this means, less vegetation cover and higher soil temperatures.

Microbiological parameters respond very quickly to perturbations in soil, and in this study we observed that both fire and post-fire management have a direct impact on the soil microbial biomass and activity. The effect of fire on microbial biomass $\left(C_{\text {mic }}\right)$ could be observed in the first two soil samplings with very low values of this parameter. This is as a consequence of the heat impact on soil microbiology (MataixSolera et al., 2009). SL treatment also affected $C_{\text {mic }}$ since the recovery with time was much lower in SL compared to $C$ area. Microbial activity measured as BSR also showed lower values at the beginning of the study with an increasing trend for the control and a decreasing trend in the SL treated area. Thus both parameters have been consistently affected by the post-fire SL treatment. Keeping the burnt wood over the soil surface avoided the loss of OM content and may supply nutrients to the soil that have encouraged the microbial population and its activity (Harmon et al., 1986; Grove, 2003; Coleman et al., 2004), our study has reported higher levels of OM, N and P in the soil of the control area without post-fire treatment. Also the trees felled on the surface would facilitate wood-soil contact and decomposition (Maser and Trappe, 1984; Harmon et al., 1986) explaining a higher BSR in these soils compared with soil without wood. The maintaining the burnt wood on the soil could also help to reduce the soil desiccation produced by the higher soil heating expected over bare soil or with less vegetation cover (Stoddard et al., 2008; Castro et al., 2011). Burnt trees and branches can act as nurse structures improving microclimatic conditions for plant regeneration (Harmon et al., 1986; Lindenmayer and Noss, 2006; Stoddard et al., 2008). These conditions promoted microorganism development and increased the rate of respiration (Marañón-Jiménez et al., 2011). On the other hand the post-fire treatment increased the negative effect of fire in the soil producing degradation processes as showed by the slower and lesser development of soil microbial populations that are closely related with structure, soil OM content and other properties (García-Orenes et al., 2010). Some other studies showed that these kinds of treatments could affect soil microbial communities (Jennings et al., 2012) and nutrient cycling (Brais et al., 2000).
In addition, SL may damage the bank of seedlings and affect plant regeneration after fire, reducing plant density (Martínez-Sánchez et al., 1999; McIver and Starr, 2001), as has been observed in our study. The significantly greater abundance of individuals in the $C$ plots means a greater plant cover. This fact represents better soil protection in the medium and long-term. This data indicates that the SL treatment clearly promoted a significant decrease in the soil seed bank that would result in a slower recovery of the original vegetation. Our study is in agreement with some other authors who observed that post-fire SL treatment reduces the vegetation cover (Serrano-Ortiz et al., 2011; Wagenbrenner et al., 2016).

\section{Conclusions}

After two years of research, results showed significant soil degradation as a consequence of the salvage logging treatment. Most of the soil parameters studied showed differences between the treatments, soil OM content in first $5 \mathrm{~cm}$ of topsoil being less than half in SL plots in comparison with $C$ area. BSR, $C_{\text {mic }}$ and AS were also statistically significant lower in SL plots. BD increased as a consequence of the SL treatment. In conclusion, we can affirm that with this type of soil, which is very vulnerable to soil degradation by erosion, the SL treatment has a very negative effect on the ecosystem, which was also reflected in the evenness of plant species. In many cases the reason given for post fire cuttings is because potential epidemic risk in unburned near forest. This only has justification in the borders between burned and unburned, where some trees are damaged but still alive. In the case that forest managers recommend to remove the post-fire vegetation we suggest to wait more time till soil is more protected by herbs and not bare and vulnerable to erosion, or doing in combination with some protective treatment like mulching. More research is needed in order to identify the SL effects in different soil type conditions, at different times after fire, and/or in combination with soil conservation treatments like mulching.

\section{Acknowledgements}

To the "Ministerio de Economía and Competitividad" of the Spanish Government for financing the POSTFIRE project (CGL2013- 47862-C2$1-\mathrm{R})$ and Alcoi council. The authors also thank Frances Young for improving the English.

\section{References}

Andreu, V., Rubio, J.L., Forteza, J., Cerní, R., 1994. Long term effects of forest fires on soil erosion and nutrient losses. In: Sala, M., Rubio, J.L. (Eds.), Soil Erosion as a Consequence of Forest Fires. Geoforma Ediciones, Logroño, pp. 79-90.

Arcenegui, V., Mataix-Solera, J., Guerrero, C., Zornoza, R., Mayoral, A.M., Morales, J., 2007. Factors controlling the water repellency induced by fire in calcareous Mediterranean forest soils. Eur. J. Soil Sci. 58, 1254-1259.

Ares, A., Terry, T.A., Miller, R.E., Anderson, H.W., Flaming, B.L., 2005. Ground-based forest harvesting effects on soil physical properties and Douglas-fir growth. Soil Sci. Soc. Am. J. 69, 1822-1832.

Benito, E. Díaz-Fierros, F. 1989. Estudio de los principales factores que intervienen en la estabilidad estructural de los suelos de Galicia. An. Edafol. Agrobiol. 48, 229-253.

Beschta, R.L., Rhodes, J.J., Kauffman, J.B., Griesswell, R.E., Minshall, G.W., Karr, J.R., Perry, D.A., Hauer, E.R., Frissell, C.A., 2004. Postfire management on forested public lands of the western United States. Conserv. Biol. 18, 957-967.

Bisdom, E.B.A., Dekker, L.W., Schoutte, J.F.T., 1993. Water repellency of sieve fractions from sandy soils and relationships with organic material and soil structure. Geoderma 56, 105-118. 
Brais, S., Paré, D., Ouirmet, R., 2000. Impacts of wild fire severity and salvage harvesting on the nutrient balance of jack pine and black spruce boreal stands. For. Ecol. Manag. 137, 231-243.

Bremner, J.M., Mulvaney, C.S., 1982. Nitrogen total. In: Page, A.L., Miller, R.H., Keeney, D.R. (Eds.), Methods of Soil Analysis, Part 2, Chemical and Microbiological Properties. American Society of Agronomy, Madison, pp. 595-624.

Brevik, E.C., 2013. Forty years of soil formation in a South Georgia, USA borrow pit. Soil Horiz. 54, 20-29.

Burton, A.J., Pregitzer, K.S., Hendrick, R.L., 2000. Relationships between fine root dynamics and nitrogen availability in Michigan northern hardwood forests. Oecologia 125 , 389-399.

Castro, J., Moreno-Rueda, G., Hodar, J.A., 2010. Experimental test of postfire management in pine forests: impact of salvage logging versus partial cutting and nonintervention on bird-species assemblages. Conserv. Biol. 24, 810-819.

Castro, J., Allen, C.D., Molina-Morales, M., Marañón-Jiménez, S., Sánchez-Miranda, A. Zamora, R., 2011. Salvage logging versus the use of burnt wood as a nurse object to promote post-fire tree seedling establishment. Restor. Ecol. 19:537-544. http://dx. doi.org/10.1111/j.1526-100X.2009.00619.x.

Cerdà, A., 1996. Soil aggregate stability in three Mediterranean environments. Soil Technol. 9, 129-133.

Certini, G., 2005. Effects of fire on properties of forest soils: a review. Oecologia 143, 1-10.

Chrenková, K., Mataix-Solera, J., Dlapa, P., Arcenegui, A., 2014. Long-term changes in soil aggregation comparing forest and agricultural land use in different Mediterranean soil types. Geoderma 235-236, 290-299.

Coleman, D.C., Crossley Jr., D.A., Hendrix, P.F., 2004. Fundamentals of Soil Ecology. Elsevier/Academic Press, Boston.

DeLuca, T.H., Aplet, G.H., 2008. Charcoal and carbon storage in forest soils of the Rocky Moutain West. Front. Ecol. Environ. 6, 18-24.

Díez, J.A., 1982. Consideraciones sobre la utilización de la técnica extractiva de BurrielHernando para la evaluación de fósforo asimilable en suelos. An. Edafol. Agrobiol. $41,1345-1353$.

Doerr, S.H., Shakesby, R.A., Walsh, R.P.D., 1998. Spatial variability of soil water repellency in fire-prone eucalyptus and pine forests, Portugal. Soil Sci. 163, 313-324.

Doerr, S.H., Dekker, L.W., Shakesby, R.A., Ritsema, C.J., Bryant, R., 2002. Water repellency of soils: the influence of ambient relative humidity. Soil Sci. Soc. Am. J. 66, 401-405.

Donato, D.C., Fontaine, J.B., Campbell, J.L., Robinson, W.D., Kauffman, J.B., Law, B.E., 2006. Post-wildfire logging hinders regeneration and increases fire risk. Science 311, 352.

Fernández, C., Vega, J.A., 2016. Effects of mulching and post-fire salvage logging on soil erosion and vegetative regrowth in NW Spain. For. Ecol. Manag. 375, 46-54.

Forster, J.C., 1995. Soil physical analysis. In: Alef, K., Nannipieri, P. (Eds.), Methods in Applied Soil Microbiology and Biochemistry. Academic Press Inc, San Diego, CA, p. 106.

Froehlich, H.A., Miles, D.W.R., Robbins, R.W., 1985. Soil bulk density recovery on compacted skid trails in Central Idaho. Soil Sci. Soc. Am. J. 49, 1015-1017.

García-Orenes, F., Guerrero, C., Roldán, A., Mataix-Solera, J., Cerdà, A., Campoy, M., Zornoza, R., Bárcenas, G., Caravaca, F., 2010. Soil microbial biomass and activity under different agricultural management systems in a semiarid Mediterranean agroecosystem. Soil Tillage Res. 109, 110-115.

Garcia-Orenes, F., Roldán, A., Mataix-Solera, J., Cerda, A., Campoy, M., Arcenegui, V., Caravaca, F., 2012. Soil structural stability and erosion rates influenced by agricultural management practices in semi-arid Mediterranean agro-ecosystem. Soil Use Manag. 28, 571-579.

González-Ochoa, A., López-Serrano, F., De las Heras, J., 2004. Does post-fire forest management increase tree growth and cone production in Pinus halepensis? For. Ecol. Manag. $188,235-247$.

Griffin, J.M., Simard, M., Turner, M.G., 2013. Salvage harvest effects on advance tree regeneration, soil nitrogen, and fuels following mountain pine beetle outbreak in lodgepole pine. For. Ecol. Manag. 291, 228-239.

Grove, S.J., 2003. Coarse woody debris, biodiversity and management: a review with particular reference to Tasmanian wet eucalypt forests. Aust. For. 66, 258-272.

Harmon, M.E., Franklin, J.F., Swanson, F.J., Sollins, P., Gregory, S.V., Lattin, J.D., Anderson, N.H., Cline, S.P., Aumen, N.G., Sedell, J.R., Lienkaemper, G.W., Cromack, K., Cummins, K.W., 1986. Ecology of coarse woody debris in temperate ecosystems. Adv. Ecol. Res. 15, 133-302.

Hatten, J., Zabowski, D., Scherer, G., Dolan, E., 2005. A comparison of soil properties after contemporary wildfire and fire suppression. For. Ecol. Manag. 220, 227-241.

Horn, R., Vossbrink, J., Becker, S., 2004. Modern forestry vehicles and their impacts on soil physical properteies. Soil Tillage Res. 79, 207-219.

Jennings, T.N., Smith, J.E., Cromack, Jr.K., Sulzman, E.W., McKay, D., Cladwell, B.A., Beldin, S.I., 2012. Impact of postfire logging on soil bacterial and fungal communities and soil biogeochemistry in mixed-conifer forest in central Oregon. Plant Soil 350, 393-411.

Keyser, T.L., Smith, F.W., Shepperd, W.D., 2009. Short-term impact of post-fire salvage logging on regeneration, hazardous fuel accumulation, and understorey development in ponderosa pine forests of the Black Hills, SD, USA. Int. J. Wildland Fire 18, 451-458.

Klock, G.O., 1975. Impact of five postfire salvage logging systems on soils and vegetation. J. Soil Water Conserv. 30, 78-81.

Larsen, I.J., MacDonald, L.H., Brown, E., Rough, D., Welsh, M.J., Pietraszek, J.H., Libohova, Z. Benavides-Solorio, J.D., Schaffrath, K., 2009. Causes of post-fire runoff and erosion; water repellency, cover, or soil sealing? Soil Sci. Soc. Am. J. 73, 1393-1407.

Le Houerou, N.H., 1977. Fire and vegetation in North Africa. En: Proc. Symp. Envir. Cons. Fire and fuel Manag. Medit. Ecosys. Forest Serv. Dep. Agric. U.S.

Lindenmayer, D.B., Noss, R.F., 2006. Salvage logging, ecosystem processes, and biodiversity conservation. Conserv. Biol. 20, 949-958.

Lindenmayer, D.B., Foster, D.R., Franklin, J.F., Hunter, M.L., Noss, R.F., Schmiegelow, F.A., Perry, D., 2004. Salvage harvesting policies after natural disturbance. Science 303. 1303.
Llovet, J., Josa, R., Vallejo, V.R., 2008. Thermal shock and rain effects on soil surface characteristics: a laboratory approach. Catena 74, 227-234.

Marañón-Jiménez, S., Castro, J., Kowalski, A.S., Serrano-Ortiz, P., Reverter, B.R., SánchezCañete, E.P., Zamora, R., 2011. Post-fire soil respiration in relation to burnt wood management in a Mediterranean mountain ecosystem. For. Ecol. Manag. 261, 1436-1447.

Marañón-Jiménez, S., Castro, J., Querejeta, J.I., Fernández-Ondoño, E., Allen, C.D., 2013 Post-fire wood management alters water stress, growth, and performance of pine regeneration in a Mediterranean ecosystem. For. Ecol. Manag. 308, 231-239.

Marques, M.A., Mora, E., 1998. Effects on erosion of two post-fire management practices: clear-cutting versus non-intervention. Soil Tillage Res. 45, 433-439.

Martínez-Sánchez, J., Ferrandis, P., las Heras, J., Herranz, J.M., 1999. Effect of burnt wood removal on the natural regeneration of Pinus halepensis after fire in a pine forest in Tus valley (SE Spain). For. Ecol. Manag. 123, 1-10.

Maser, C., Trappe, J.M., 1984. The seen and unseen world of the fallen tree. Forest Service General Technical Report PNW-164. Portland, United States Department of Agriculture, Forest Service.

Mataix-Solera, J., Gómez, I., Navarro-Pedreño, J., Guerrero, C., Moral, R., 2002. Soil organic matter and aggregates affected by wildfire in a Pinus halepensis forest in a Mediterranean environment. Soil Tillage Res. 11, 107-114.

Mataix-Solera, J., Guerrero, C., García-Orenes, F., Bárcenas, G.M., Torres, M.P., 2009. Forest fire effects on soil microbiology. In: Cerdà, A., Robichaud, P. (Eds.), Fire Effects on Soils and Restoration Strategies. Science Publishers, Inc, Enfield, New Hampshire USA pp. 133-175.

Mataix-Solera, J., Arcenegui, V., Zavala, L.M., Pérez-Bejarano, A., Jordán, A., MorugánCoronado, A., Bárcenas-Moreno, G., Jiménez-Pinilla, P., Lozano, E., Granged, A.J.P. Gil-Torres, J., 2014. Small variations of soil properties control fire-induced water repellency. Span. J. Soil Sci. 4, 51-60.

Mataix-Solera, J., Molto, J., Arcenegui, V., García-Orenes, F., Chrenková, K., Torres, P., JaraNavarro, A.B., Diaz, A., Izquierdo, E., 2015. Salvage logging effect on soil properties in fire-affected Mediterranean forest: a two years monitoring research. Geophys. Res. Abstr. 17, 2460-2462.

Mataix-Solera, J., Arnaiz, P., Arcenegui, V., Chrenkovà, K., López-Caravaca, A., GarcíaOrenes, F., Jara-Navarro, A.B., Cerdà, A., 2016. Hydrological response 3 years after salvage logging treatments in a recently burnt forest soil. European Society for Soil Conservation Conference. Cluj-Napoca, Romania. 15-18 June 2016. Abstracts Book, p. 47

McIver, J.D., McNeil, R., 2006. Soil disturbance and hill-slope sediment transport after logging of a severely burned site in northeastern Oregon. West. J. Appl. For. 21, 123-133.

McIver, J.D., Starr, L., 2001. A literature review on the environmental effects of postfire logging. West. J. Appl. For. 16, 159-168.

Morgan, P., Moy, M., Droske, C.A., Lewis, S.A., Lentile, L.B., Robichaud, P.R., Hudak, A.T. Williams, C.J., 2014. Vegetation response to burn severity, native grass seeding, and salvage logging. Fire Ecol. 10, 31-58.

Moroni, M.T., Shaw, C.H., Otahal, P., 2010. Forest carbon stocks in Newfoundland borea forests of harvest and natural disturbance origin I: field study. Can. J. For. Res. 40, 2135-2145.

Nadelhoffer, K.J., 2000. The potential effects of nitrogen deposition on fine-root production in forest ecosystems. New Phytol. 147, 131-139.

Naveh, Z., 1975. The evolutionary significance of fire in the Mediterranean region. Vegetatio 29, 199-208.

Nelson, D.V., Sommers, L.E., 1982. Total carbon, organic carbon, and organic matter. In: A.L. (Ed.), Methods of Soil Analysis, Part 2. Chemical and Biological Methods, p. 816.

Page-Dumroese, D.S., Jurgensen, M.F., Tiarks, A.E., Ponder, J.F., Sanchez, F.G., Fleming, R.L Kranabetter, J.M., Powers, R.F., Stone, D.M., Elioff, J.D., Scott, D.A., 2006. Soil physical property changes at the North American long-term soil productivity study sites: 1 and 5 years after compaction. Can. J. For. Res. 36, 551-564.

Pausas, J.G., Ribeiro, E., Vallejo, R., 2004. Post-fire regeneration variability of Pinus halepensis in the eastern Iberian Peninsula. For. Ecol. Manag. 203, 251-259.

Peterson, D.W., Dodson, E.K., 2016. Post-fire logging produces minimal persistent impacts on understory vegetation in northeastern Oregon, USA. For. Ecol. Manag. 370, 56-64.

Purdon, M., Brais, S., Bergeron, Y., 2004. Initial response of understorey vegetation to fire severity and salvage-logging in the southern boreal forest of Québec. Appl. Veg. Sci. 7 49-60.

Reisinger, T.W., Pope, P.E., Hammond, S.C., 1992. Natural recovery of compacted soils in an upland hardwood forest in Indiana. North. J. Appl. For. 9 (4), 138-141.

Ritchie, M.W., Knapp, E.E., Skinner, C.N., 2013. Snag longevity and surface fuel accumulation following post-fire logging in a ponderosa pine dominated forest. For. Ecol Manag. 287, 113-122.

Robichaud, P., 2009. Using erosion barriers for post-fire stabilization. In: Cerdá, A. Robichaud, P. (Eds.), En: Fire Effects on Soils and Restoration Strategies. Science Publishers, pp. 337-352.

Roldán, A., García-Orenes, F., Lax, A., 1994. An incubation experiment to determinate factors involving aggregation changes in an arid soil receiving urban refuse. Soil Biol. Biochem. 26, 1699-1707.

Seedre, M., Shrestha, B.M., Chen, H.Y.H., Colombo, S., Jõgiste, K., 2011. Carbon dynamics of North American boreal forest after stand replacing wildfire and clearcut logging. J. For. Res. 16, 168-183.

Serrano-Ortiz, P., Marañón-Jiménez, S., Reverter, B.R., Sánchez-Cañete, E.P., Castro, J., Kowalski, A.S., 2011. Post-fire salvage logging reduces carbon sequestration in Mediterranean coniferous forest. For. Ecol. Manag. 262, 2287-2296.

Sexton, T.O., 1998. Ecological Effects of Post-Wildfire Management Activities (SalvageLogging and Grass-Seeding) on Vegetation Composition, Diversity, Biomass, and Growth and Survival of Pinus ponderosa and Purshia tridentata. M.S. thesis Oregon State University. 
Slestak, R.A., Schoenholtz, S.H., Evans, D., 2015. Hillslope erosion two and three years after wildfire, skyline salvage logging, and site preparation in southern Oregon, USA. Forest Ecol. Manag. 342, 1-7.

Smith, K.C., Coyea, M.R., Munson, A.D., 2000. Soil carbon, nitrogen, and phosphorus stocks and dynamics under disturbed black spruce forests. Ecol. Appl. 10, 775-788.

Soil Survey Staff, 2014. Keys to Soil Taxonomy. 12th ed. USDA-Natural Resources Conservation Service, Washington, DC

Startsev, A.D., McNabb, D.H., 2000. Effects of skidding on forest soil infiltration in westcentral Alberta. Can. J. Soil Sci. 80, 617-624.

Stoddard, M.T., Huffman, D.W., Alcoze, T.M., Fule, P.Z., 2008. Effects of slash on herbaceous communities in pinyon-juniper woodlands of northern Arizona. Rangel. Ecol. Manag. 61, 485-495.

Stuart, J.D., Grifantini, M.C., Fox III, L., 1993. Early successional pathways following wildfire and subsequent silvicultural treatment in Douglas-fir/hardwood forests, NW California. For. Sci. 39, 561-572.

Tang, J.W., Baldocchi, D.D., Qi, Y., Xu, L.K., 2003. Assessing soil $\mathrm{CO}_{2}$ efflux using continuous measurements of $\mathrm{CO}_{2}$ profiles in soils with small solid-state sensors. Agric. For. Meteorol. 118, 207-220.

Vance, E.D., Brookes, P.C., Jenkinson, D.S., 1987. An extraction method for measuring soil microbial biomass C. Soil Biol. Biochem. 19, 703-707.

Vega, J.A., Fernández, C., Pérez-Gorostiaga, P., Fonturbel, T., 2008. The influence of fire severity, serotiny, and post-fire management on Pinus pinaster Ait. recruitment in three burnt areas in Galicia (NW Spain). For. Ecol. Manag. 256, 1596-1603.
Vora, R.S., 1988. Potential soil compaction forty years after logging in Northeastern California. Great Basin Nat. 48 (1), 117-120.

Wagenbrenner, J.W., Robichaud, P.R., 2014. Post-fire bedload sediment delivery across spatial scales in the interior western US. Earth Surf. Process. Landf. 39, 865-876.

Wagenbrenner, J.W., MacDonald, L.H., Coats, R.N., Robichaud, P.R., Brown, R.E., 2015. Effects of post-fire salvage logging and a skid trail treatment on ground cover, soils, and sediment production in the interior western United States. For. Ecol. Manag. 335, 176-193.

Wagenbrenner, J.W., Robichaud, P.R., Brown, R.E., 2016. Rill erosion in burned and salvage logged western montana forests: effects of logging equipment type, traffic level, and slash treatment. J. Hydrol. 541, 889-901.

Wert, S., Thomas, B.R., 1981. Effects of skid roads on diameter, height, and volume growth in Douglas-fir. Soil Sci. Soc. Am. J. 45, 629-632.

Wessel, A.T., 1988. On using the effective contact angle and the water drop penetration time for classification of water repellency in dune soils. Earth Surf. Process. Landf. $13,555-562$.

Wilson, C.J., 1999. Effects of logging and fire on runoff and erosion on highly erodible granitic soils in Tasmania. Water Resour. Res. 35, 3531-3546.

Zornoza, R., Mataix-Solera, J., Guerrero, C., Arcenegui, V., Mayoral, A.M., Morales, J., Mataix-Beneyto, J., 2007. Soil properties under natural forest in the Alicante Province of Spain. Geoderma 142, 334-341. 